\title{
Morphometric and Phylogenic Analysis of Six Population Indonesian Local Goats
}

\author{
A. Batubara ${ }^{a, b, \#, *}$, R. R. Noor ${ }^{a, \#}$, A. Farajallah ${ }^{c, \#}$, B. Tiesnamurti ${ }^{d}, \&$ M. Doloksaribu ${ }^{b}$ \\ ${ }^{a}$ Department of Animal Production and Technology, Graduate School, Bogor Agricultural University \\ bIndonesian Goat Research Institute \\ Sei Putih, Galang 20585, North Sumatera, Indonesia \\ 'Department of Biology, Faculty of Mathemetic and Natural Science, Bogor Agricultural University \\ "Jln. Agatis, Kampus IPB Darmaga, Bogor 16680, Indonesia \\ ${ }^{\mathrm{d}}$ Central Research Institute for Animal Science \\ Jln. Veteran III, Desa Banjarwaru, Ciawi - Bogor 16002, Indonesia \\ (Received 29-10-2010; accepted 25-03-2011)
}

\begin{abstract}
ABSTRAK
Tujuan penelitian adalah untuk mengkarakterisasi ukuran-ukuran tubuh (morfometrik) dan jarak genetik antara enam populasi kambing lokal Indonesia. Analisis morfometrik dan kanonikal dilakukan untuk mengetahui hubungan kekerabatan dan ukuran tubuh yang dominan untuk menentukan pengelompokan pada kambing Benggala $(n=96)$, Marica $(n=60)$, Jawarandu $(n=94)$, Kacang $(n=217)$, Muara $(n=30)$, dan Samosir $(n=42)$. Analisis diskriminan digunakan untuk mengelompokkan parameter bobot badan dan ukuran-ukuran tubuh. Hasil penelitian menunjukkan bahwa bobot badan dan ukuran-ukuran tubuh (panjang badan, tinggi pundak, lebar dada, tinggi pundak, lingkar dada, tinggi dan lebar tengkorak, panjang dan lebar ekor, panjang dan lebar telinga) pada kambing Muara lebih tinggi $(P<0,05)$ dibandingkan dengan populasi kambing lainnya, dan paling rendah pada kambing Marica. Jarak genetik paling dekat terdapat pada kambing Marica dan Samosir $(11,207)$ dan paling jauh pada kambing Muara dan Benggala $(255,110)$. Tingkat kesamaan paling tinggi antar individu dalam populasi dijumpai pada kambing Kacang $(99,28 \%$ ) dan paling rendah pada kambing Samosir $(82,50 \%)$. Analisis kanonikal menunjukkan bahwa ukuran tubuh paling dominan sebagai pembeda antar enam populasi kambing lokal yang diamati antara lain: lingkar kanon, ukuran tubuh, lebar tengkorak, tinggi tengkorak, dan lebar ekor. Hasil analisis jarak mahalonobis pohon fenogram dan kanonikal menunjukkan bahwa enam populasi masing-masing berdiri sendiri, sehingga dibedakan menjadi enam rumpun, yaitu rumpun kambing Muara, Jawarandu, Kacang, Benggala, Samosir, dan Marica. Tingkat keragaman bobot badan dan panjang badan sangat tinggi, sehingga peluang peningkatan produksi dapat dilakukan melalui program persilangan dan seleksi.
\end{abstract}

Kata kunci: morfometrik, analisis diskriminan, kambing lokal

\section{ABSTRACT}

The research objectives were to characterize morphometric and genetic distance between populations of Indonesian local goats. The morphological discriminant and canonical analysis were carried out to estimate the phylogenic relationship and determine the discriminant variable between Benggala goats $(n=96)$, Marica $(n=60)$, Jawarandu $(n=94)$, (Kacang $(n=217)$, Muara $(n=30)$ and Samosir $(n=42)$. Discriminant analysis used to clasify body weight and body measurements. In the analysis of variance showed that body weight and body measurement (body length, height at withers, thorax width, thorax height, hert girth, skull width and height, tail length and width, ear length and width) of Muara goats was higher $(P<0.05)$ compared to the other groups, and the lowest was in Marica goats. The smallest genetic distance was between Marica and Samosir (11.207) and the highest were between Muara and Benggala (255.110). The highest similarity between individual within population was found in Kacang $(99.28 \%)$ and the lowest in Samosir $(82.50 \%)$. The canonical analysis showed high correlation on canon circumference, body weight, skull width, skull height, and tail width variables so these six variables can be used as distinguishing variables among population. The result from Mahalonobis distance for phenogram tree and canonical analysis showed that six populations of Indonesian local goats were divided into six breed of goats: the first was Muara, the second

\footnotetext{
*Corresponding author:

e-mail: aronbatubara@yahoo.com
} 


\begin{abstract}
was Jawarandu, the third was Kacang, the fourth was Benggala, the fifth was Samosir and the sixth was Marica goats. The diversity of body size and body weight of goats was observed quite large, so the chances of increasing productivity could be made through selection and mating programs.
\end{abstract}

Key words: morphometrics, discriminant analysis, local goats

\section{INTRODUCTION}

Local goat is a great potential genetic resource to be utilized as a source of superior breeding formulation which adaptable to local conditions in Indonesia. FAO (2007) reported that breeds of local livestock is important to be protected because it has its own advantages, which can survive with low-quality feed, able to survive the pressure of the local climate changes, high resistance to local diseases and parasites, is a unique source of genes for use in repairing the breeds through the crossing, be more productive with lower costs, support diversity in the long term, support the diversity of food, agriculture and culture, is more effective in achieving local food security.

Goats husbandry play an important role in small livestock farmers to improve incomes and also as a source of meat, manure for fertilizer, money, family labor optimization, improved social status, and socio-cultural aspects. Based on the statistics data in 2009 (Directorate General of Livestock, 2010) total goat population in Indonesia as much as 15,655,740 heads; the highest in Central Java province (3,491,073 heads); East Java (2,780,822 heads); West Java (1,488,152 heads); Lampung (1012 .705 tail); Banten (854,522 heads); Namro Aceh Darussalam (703 594 heads); North Sumatra $(619,940$ heads); NTT $(547,234$ heads); and South Sulawesi (435,103 heads). Nearly $99 \%$ of small ruminants in Indonesia are small-scale livestock enterprises. Goats can convert low-quality forages into animal protein, as a source of manure as well as savings.

External appearance (morphology) is still commonly used by researchers and practitioners in identifying farms, characterization and selection of animals to breed (Khan et al., 2006; Dossa et al., 2007; Alade et al., 2008; Jimmy et al., 2010). Observations on the outside view are the easiest thing to do, but the appearance of this morphology is heavily influenced by external environmental factors such as availability of food and climate (Anderson, 2001; Lanari et al., 2003; Salako, 2006; Jing et al., 2010). The presence of animals caused by animal adaptation capability has the ability to produce more than one alternative form of morphology, physiological status, and or behavior as a reaction or adaptation to environmental changes in the form of regulation of gene expression and changes in shape phenotype (Karna et al., 2001; Noor, 2002; Riva et al., 2004; Mansjoer et al., 2007).

The existing characteristics of some local goats in different regions showed many performance varieties. Since the last two centuries there were several types of goats imported to Indonesia, thereby increased genetic diversities of goats in Indonesia. For the purpose of wealth preservation and development potential of livestock germ plasma is very necessary to explore and identify genetic diversity of local goat resources in Indonesia. Indonesia Animal Production Research Institute has begun to characterize Kacang, Peranakan Ettawah, Jawarandu, Kosta and Gembrong goats (Sitepu, 1985; Subandriyo et al., 1995; Setiadi et al., 1997). It is estimated that there are some Indonesian local goat breeds that still not characterized yet and some might be nearly as the populations of rare or nearing extinction. The purpose of this study was to obtain data and information on the characteristics and genetic diversity among local goats in Indonesia.

\section{MATERIALS AND METHODS}

\section{Animal and Data Sampling Collection}

The study was conducted at several populations in the four Provinces, namely; Marica goat from South Sulawesi (Maros Regency and Jeneponto Regency), Benggala goat (B) of Nusa Tenggara Timur (Timor and Flores island), Jawarandu goat (J) from Central Java (Blora Regency), and 3 populations of North Sumatra (Kacang goat (K) from Indonesian Goat Research Institute station, Samosir goat (S) of Samosir Regency, and Muara goat (R) of the Regency of North Tapanuli). Goat samples made in random order, each region as much as 96 head Benggala, 94 head Jawarandu, 60 head Marica, 217 head Kacang, 30 head Muara, and 42 head Samosir goats. Phenotypic parameters used in data analysis include: shoulders height, body length, chest tight, chest width, chest circumference, skull length, skull width, tail length, tail width, ear length, and ear width. The name of goat is used as covariates goat populations.

\section{Statistical Analysis}

Analysis of variance (ANOVA) was used to calculate the effect of body sizes between populations. If the result is significantly different, it will be continued with the Duncan test analysis.

\section{Morphometric Analysis}

Simple discriminant function performed for the determigenotype of genetic distance (Traore et al., 2008). The discriminant function used by the Mahalanobis distance approach as described by Nei \& Nei (1987) and Flury (1988), where the matrix diversity range between variables of each population of goats were observed combined (pooled) into one matrix. The pooled matrix can be explained in the following form: 


$$
\mathbf{C}=\left(\begin{array}{llll}
c_{11} & c_{12} & \ldots . & c_{1 p} \\
c_{21} & c_{22} & \ldots . & c_{2 p} \\
c_{31} & c_{32} & \ldots . & c_{3 p} \\
c_{p 1} & c_{p 2} & \ldots . & c_{p p}
\end{array}\right)
$$

To get the minimum genetic distance used quadratic formula in accordance with the instructions of Everitt et al. (2001) and Quinn et al. (2002) as follows:

$$
\text { D2 }(i, j)=(x i-x j) C-1(x i-x j)
$$

Description:

D2 $(i, j)=$ value Mahalanobis statistic as a measure of genetic distance between the two breed squared/genotype goats (between genotypes in relation to the $\mathrm{j}$-th genotype).

$\mathrm{C}-1=$ reverse matrix composite diversity range between variables.

$\mathrm{X} \mathrm{i}=$ vector value of the mean observation of goat genotype i at each quantitative variable.

$\mathrm{x} \mathrm{j}=$ vector observations from the mean value of the $\mathrm{j}$-th goat genotype on quantitative variables respectively.

The Mahalanobis statistical analysis with the DISCRIM procedure and the CANDISC procedure using the SAS version 9.1 program (SAS Inst., 2005). From the quadratic distance calculations was transformed to the square root data. The square root data was analyzed by MEGA program (Tamura et al., 2007) as Kumar et al. (1993) methods to obtain the phenogram tree. The Canonical analysis (Herrera et al., 1996) was conducted to determine the map of the spread of goat, and the similarities value and mix within and between population of goats.

\section{RESULTS AND DISCUSSION}

\section{Body Weight and Body Size Parameters}

The highest average of body weight of adult female (doe) was in Muara goat (37.46 kg) significantly different $(\mathrm{P}<0.05)$ when compared 5 other population groups. The mean and standard deviation for female goat (doe), male goats (buck) and over all of body weigth were shown in
Table 1. The average body weight of Samosir doe was $25 \mathrm{~kg}$ similar with Benggala and Jawarandu, higher than Marica and Kacang goats respectively. Average body weight of adult male (buck) was highest in the Muara goat $(49 \mathrm{~kg})$ significantly different $(\mathrm{P}<0.05)$ with the other five genotypes. Average body weight Kacang buck was $24.67 \mathrm{~kg}$, Samosir (22 kg) similar with Marica, Jawarandu (16.36 kg) almost similar with Benggala buck. The results showed that the goats body weight between populations were significantly different $(\mathrm{P}<0.005)$. Muara goat was the heaviest $(38.23 \mathrm{~kg})$, followed by Samosir $(24.57 \mathrm{~kg})$ and Benggala goat $(24.09 \mathrm{~kg})$ in the second rank, Kacang (21.95 kg) and Jawarandu $(21.15 \mathrm{~kg})$ in the third rank, and than Marica goat $(20.53 \mathrm{~kg})$ was the smallest in body weight. The average of body weight of doe and buck for Kacang and Jawarandu in this study lower compared with the research reported by Setiadi et al. (1997) in the Purworejo Regency were $23.83 \mathrm{~kg}$ and $26.88 \mathrm{~kg}$ for Kacang goat, $28.74 \mathrm{~kg}$ and $30.91 \mathrm{~kg}$ for Jawarandu goats. The body weight difference was presumebaly caused by differences in breeding stock quality and its management system in the Purworejo better than in the Blora Regency.

The average parameter goat's body sizes among population were significantly different $(\mathrm{P}<0.05)$ (Table $2)$. The highest wither height of doe was in Muara significantly different $(\mathrm{P}<0.05)$ when compared with the other populations. Kacang doe wither height almost similar with Benggala and Samosir, and Jawarandu wither height almost similar with Marica. The highest wither height of buck also in Muara was significantly different when compared with other populations, from the highst to the lower were Kacang almost similar with Marica and Samosir, and the lowest were Jawarandu and Benggala bucks. The highest average body length of adult doe was found in Muara $(72.82 \mathrm{~cm})$ significantly different $(\mathrm{P}<0.05)$ with the other population. From the highest body length of doe to the lower were Samosir similar with Benggala, higher than Kacang, the lowest was Marica and Jawarandu respectively. The highest of buck body length was in Muara and than Samosir similar with Marica and Kacang, Benggala higher than Jawarandu respectively. The highest average chest width of doe was found in Marica almost similar with Samosir and Muara, and than Jawarandu similar with Kacang

\begin{tabular}{|c|c|c|c|c|c|c|c|}
\hline \multirow{2}{*}{$\begin{array}{l}\text { Goat sub } \\
\text { populations }\end{array}$} & \multicolumn{2}{|c|}{ Doe } & \multicolumn{2}{|c|}{ Buck } & \multicolumn{3}{|c|}{ Overall } \\
\hline & $\mathrm{n}$ & $\mathrm{x} \pm \mathrm{sd}(\mathrm{kg})$ & $\mathrm{n}$ & $\mathrm{x} \pm \mathrm{sd}(\mathrm{kg})$ & $\mathrm{n}$ & $\mathrm{x} \pm \mathrm{sd}(\mathrm{kg})$ & CV (\%) \\
\hline Benggala (B) & 89 & $24.73 \pm 8.69^{b}$ & 7 & $16.00 \pm 3.87^{c}$ & 96 & $24.09 \pm 8.72^{\mathrm{b}}$ & 36.20 \\
\hline Jawarandu (J) & 72 & $23.11 \pm 7.87^{c}$ & 22 & $16.36 \pm 4.79^{c}$ & 94 & $21.15 \pm 7.79^{c}$ & 36.19 \\
\hline Kacang (K) & 193 & $21.61 \pm 5.86^{c}$ & 24 & $24.67 \pm 6.09^{b}$ & 217 & $21.95 \pm 5.95^{b c}$ & 27.12 \\
\hline Marica (M) & 48 & $20.88 \pm 6.61^{c}$ & 12 & $19.17 \pm 5.27^{\mathrm{bc}}$ & 60 & $20.53 \pm 6.36^{c}$ & 30.98 \\
\hline Muara (R) & 28 & $37.46 \pm 11.01^{\mathrm{a}}$ & 2 & $49.00 \pm 26.87^{a}$ & 30 & $38.23 \pm 12.10^{\mathrm{a}}$ & 31.64 \\
\hline Samosir (S) & 36 & $25.00 \pm 5.42^{\mathrm{b}}$ & 6 & $22.00 \pm 8.10^{\mathrm{bc}}$ & 42 & $24.57 \pm 5.86^{\mathrm{b}}$ & 23.82 \\
\hline
\end{tabular}

Table 1. Mean body weight of 6 populations Indonesian local goats

Note: Means in the same column with different superscript differ significantly $(\mathrm{P}<0.05) ; \mathrm{n}=$ number of samples; $\mathrm{x}=$ average; sd= standard deviation; $\mathrm{CV}=$ coefficient variance. 
Table 2. Mean of the shoulder height, body length, chest width, chest depth, and chest circumference of doe and buck

\begin{tabular}{|c|c|c|c|c|c|c|c|}
\hline \multirow{2}{*}{ Parameters } & \multirow{2}{*}{$\begin{array}{c}\text { Goat sub } \\
\text { popula- } \\
\text { tions }\end{array}$} & \multicolumn{3}{|c|}{ Doe } & \multicolumn{3}{|c|}{ Buck } \\
\hline & & $\mathrm{x} \pm \mathrm{sd}(\mathrm{cm})$ & $\mathrm{n}$ & $\mathrm{CV}(\%)$ & $\mathrm{x} \pm \mathrm{sd}(\mathrm{cm})$ & $\mathrm{n}$ & $\mathrm{CV}(\%)$ \\
\hline \multirow[t]{6}{*}{ Wither height } & B & $55.30 \pm 7.05^{\mathrm{b}}$ & 89 & 12.76 & $47.71 \pm 4.89^{c}$ & 7 & 10.25 \\
\hline & $\mathrm{J}$ & $52.47 \pm 7.69^{\mathrm{cd}}$ & 72 & 14.65 & $48.91 \pm 6.88^{c}$ & 22 & 14.07 \\
\hline & K & $55.62 \pm 4.22^{\mathrm{b}}$ & 193 & 7.58 & $56.33 \pm 4.44^{\mathrm{b}}$ & 24 & 7.88 \\
\hline & M & $51.42 \pm 5.15^{\mathrm{d}}$ & 48 & 10.02 & $51.17 \pm 5.86^{\mathrm{bc}}$ & 12 & 11.45 \\
\hline & $\mathrm{R}$ & $65.29 \pm 3.82^{\mathrm{a}}$ & 28 & 5.58 & $78.00 \pm 11.31^{\mathrm{a}}$ & 2 & 14.50 \\
\hline & S & $54.50 \pm 4.35^{\mathrm{bc}}$ & 36 & 7.97 & $50.56 \pm 5.09^{\mathrm{bc}}$ & 6 & 10.04 \\
\hline \multirow[t]{6}{*}{ Body length } & B & $61.56 \pm 9.12^{\mathrm{bc}}$ & 89 & 14.81 & $51.41 \pm 3.98^{\mathrm{bc}}$ & 7 & 7.77 \\
\hline & $\mathrm{J}$ & $53.06 \pm 11.29^{d}$ & 72 & 21.29 & $46.36 \pm 6.51^{c}$ & 22 & 14.03 \\
\hline & K & $58.87 \pm 5.58^{c}$ & 193 & 9.47 & $58.00 \pm 3.01^{\mathrm{b}}$ & 24 & 5.18 \\
\hline & M & $54.92 \pm 5.09^{d}$ & 48 & 9.26 & $58.67 \pm 14.33^{b}$ & 12 & 24.43 \\
\hline & $\mathrm{R}$ & $72.82 \pm 6.99^{a}$ & 28 & 9.60 & $76.50 \pm 14.85^{\mathrm{a}}$ & 2 & 19.41 \\
\hline & S & $63.44 \pm 5.07^{\mathrm{b}}$ & 36 & 8.00 & $59.33 \pm 7.89^{\mathrm{b}}$ & 6 & 13.30 \\
\hline \multirow[t]{6}{*}{ Chest width } & B & $11.48 \pm 4.83^{\mathrm{b}}$ & 89 & 42.03 & $17.71 \pm 3.77^{\mathrm{ab}}$ & 7 & 21.30 \\
\hline & $\mathrm{J}$ & $12.60 \pm 3.64^{\mathrm{b}}$ & 72 & 28.87 & $10.36 \pm 3.72^{c}$ & 22 & 35.92 \\
\hline & K & $11.61 \pm 2.14^{\mathrm{b}}$ & 193 & 18.40 & $15.00 \pm 2.64^{\mathrm{b}}$ & 24 & 17.58 \\
\hline & M & $16.25 \pm 3.19^{a}$ & 48 & 19.60 & $15.83 \pm 3.10^{\mathrm{b}}$ & 12 & 19.57 \\
\hline & $\mathrm{R}$ & $15.11 \pm 3.37^{\mathrm{a}}$ & 28 & 27.54 & $21.00 \pm 3.49^{a}$ & 2 & 53.03 \\
\hline & S & $15.25 \pm 2.29^{a}$ & 36 & 14.98 & $14.50 \pm 3.51^{\mathrm{b}}$ & 6 & 24.19 \\
\hline \multirow[t]{6}{*}{ Chest depth } & B & $20.56 \pm 5.56^{a}$ & 89 & 27.05 & $27.71 \pm 3.77^{\mathrm{b}}$ & 7 & 13.62 \\
\hline & $\mathrm{J}$ & $27.33 \pm 4.07^{\mathrm{b}}$ & 72 & 14.90 & $24.82 \pm 4.20^{\mathrm{b}}$ & 22 & 16.94 \\
\hline & K & $25.61 \pm 2.14^{c}$ & 193 & 8.34 & $29.00 \pm 2.64^{\mathrm{b}}$ & 24 & 9.09 \\
\hline & M & $27.25 \pm 3.19^{b}$ & 48 & 11.69 & $26.83 \pm 3.10^{\mathrm{b}}$ & 12 & 11.15 \\
\hline & $\mathrm{R}$ & $30.25 \pm 3.37^{\mathrm{a}}$ & 28 & 11.15 & $34.00 \pm 8.49^{\mathrm{a}}$ & 2 & 24.96 \\
\hline & S & $26.25 \pm 2.29^{b c}$ & 36 & 8.70 & $25.50 \pm 3.51^{\mathrm{b}}$ & 6 & 13.75 \\
\hline \multirow{6}{*}{$\begin{array}{l}\text { Chest circum } \\
\text { ference }\end{array}$} & B & $68.35 \pm 7.81^{\mathrm{b}}$ & 89 & 11.43 & $57.86 \pm 5.52^{\mathrm{bc}}$ & 7 & 9.54 \\
\hline & $\mathrm{J}$ & $64.28 \pm 9.62^{c}$ & 72 & 14.97 & $54.73 \pm 7.34^{c}$ & 22 & 13.42 \\
\hline & K & $63.15 \pm 7.03^{c}$ & 193 & 11.13 & $66.67 \pm 5.16^{\mathrm{b}}$ & 24 & 7.75 \\
\hline & M & $63.71 \pm 6.81^{c}$ & 48 & 10.69 & $61.33 \pm 7.35^{\mathrm{bc}}$ & 12 & 11.99 \\
\hline & $\mathrm{R}$ & $79.93 \pm 8.19^{a}$ & 28 & 10.24 & $85.50 \pm 17.68^{\mathrm{a}}$ & 2 & 20.68 \\
\hline & $S$ & $66.00 \pm 6.13^{\mathrm{bc}}$ & 36 & 9.29 & $59.83 \pm 12.77^{\mathrm{bc}}$ & 6 & 21.34 \\
\hline
\end{tabular}

Note: Means in the same column with different superscript differ significantly ( $<<0.05)$; K= Kacang; B= Benggala; $\mathrm{S}=\mathrm{Samosir}$; J= Jawarandu; M= Marica; $\mathrm{R}=$ Muara; $\mathrm{n}=$ number of samples; $\mathrm{x}=$ average; $\mathrm{sd}=$ standard deviation; $\mathrm{CV}=$ coefficient variance.

and Benggala goats. The highest chest width of buck was in Muara similar with Benggala, Marica similar with Samosir and Kacang, and the lowest was Jawarandu. The highest chest depth of doe were found in Muara similar with Benggala, significantly different $(\mathrm{P}<0.05)$ compare to others four populations, than followed by Jawarandu similar with Marica and Samosir, and the lowest was Kacang. The highest buck chest depth was in Muara significantly different $(\mathrm{P}<0.05)$ compared to other five populations. The average buck chest depth of Samosir was similar to Marica, Kacang, Jawarandu, and Benggala goats. The highest average chest circumference was found in Muara significantly different $(\mathrm{P}<0.05)$ compared to other five genotypes, Benggala similar with Samosir and the lowest Kacang similar to Marica and Jawarandu. The highest chest circumference of buck found in Muara significantly different $(\mathrm{P}<0.05)$ compared to other five populations, followed by Kacang, Marica similar to Samosir and Benggala, and the lowest was Jawarandu goat.

The average of skull size parameters among goat population were significantly different $(\mathrm{P}<0.05)$ (Table $3)$. The highest skull length of doe were in Kacang similar with Benggala, and than from the the higher Muara, Jawarandu similar with Marica and Samosir. The highest skull length of buck was in Muara and Kacang, than Benggala similar to Samosir, Jawarandu, and Marica. The highest skull width size of doe was Muara significantly different $(\mathrm{P}<0.05)$ compared to Samosir similar with Kacang, than Benggala similar with Jawarandu, 
and the lowest was Marica. The highest skull width of buck was in Muara significantly different $(\mathrm{P}<0.05)$ compared to Kacang, than Jawarandu similar to Benggala and Marica, and the lowest was Samosir. The highest skull height of doe was Muara significantly different $(\mathrm{P}<0.05)$ compared to Samosir similar with Kacang, and
Benggala similar to Jawarandu and Marica. The highest skull height of buck skull was Muara significantly different $(\mathrm{P}<0.05)$ compared to Kacang, and than Samosir similar to Marica, Benggala, and Jawarandu.

In general, the average tail length and width of 6 populations were significantly different $(\mathrm{P}<0.05)$ when

Table 3. Mean of the skull length, skull width, and skull height of buck and doe adult of six Indonesian local goats

\begin{tabular}{|c|c|c|c|c|c|c|c|}
\hline \multirow{2}{*}{ Parameters } & \multirow{2}{*}{$\begin{array}{l}\text { Goat } \\
\text { popula- } \\
\text { tions }\end{array}$} & \multicolumn{3}{|c|}{ Doe } & \multicolumn{3}{|c|}{ Buck } \\
\hline & & $\mathrm{x} \pm \mathrm{sd}(\mathrm{cm})$ & $\mathrm{n}$ & CV (\%) & $\pm \mathrm{SD}(\mathrm{cm})$ & $\mathrm{n}$ & $\mathrm{CV}(\%)$ \\
\hline \multirow[t]{6}{*}{ Skull length } & B & $15.30 \pm 1.88^{\mathrm{ab}}$ & 89 & 12.28 & $12.86 \pm 1.46^{\mathrm{b}}$ & 7 & 11.39 \\
\hline & $\mathrm{J}$ & $14.08 \pm 2.52^{\mathrm{cd}}$ & 72 & 17.87 & $12.36 \pm 1.81^{\mathrm{b}}$ & 22 & 14.67 \\
\hline & K & $15.68 \pm 1.38^{\mathrm{a}}$ & 193 & 8.78 & $15.67 \pm 1.40^{\mathrm{a}}$ & 24 & 8.96 \\
\hline & M & $13.73 \pm 1.77^{\mathrm{d}}$ & 48 & 12.90 & $13.00 \pm 1.35^{\mathrm{b}}$ & 12 & 10.37 \\
\hline & $\mathrm{R}$ & $14.64 \pm 1.54^{\mathrm{bc}}$ & 28 & 10.55 & $16.00 \pm 2.83^{\mathrm{a}}$ & 2 & 17.68 \\
\hline & S & $13.69 \pm 1.86^{\mathrm{d}}$ & 36 & 13.61 & $13.33 \pm 1.97^{\mathrm{b}}$ & 6 & 14.75 \\
\hline \multirow[t]{6}{*}{ Skull width } & B & $10.53 \pm 1.30^{\text {cd }}$ & 89 & 12.33 & $8.71 \pm 0.76^{\mathrm{d}}$ & 7 & 8.67 \\
\hline & $\mathrm{J}$ & $10.28 \pm 2.09^{\mathrm{de}}$ & 72 & 20.35 & $9.18 \pm 1.14^{\mathrm{d}}$ & 22 & 12.41 \\
\hline & K & $10.97 \pm 1.19^{\mathrm{bc}}$ & 193 & 10.81 & $12.33 \pm 0.48^{\mathrm{b}}$ & 24 & 3.90 \\
\hline & M & $9.79 \pm 1.27^{\mathrm{e}}$ & 48 & 12.98 & $8.67 \pm 0.49^{\mathrm{d}}$ & 12 & 5.68 \\
\hline & $\mathrm{R}$ & $13.79 \pm 2.91^{\mathrm{a}}$ & 28 & 21.11 & $13.50 \pm 2.12^{\mathrm{a}}$ & 2 & 15.71 \\
\hline & S & $11.56 \pm 2.45^{\mathrm{b}}$ & 36 & 21.24 & $10.67 \pm 0.82^{\mathrm{c}}$ & 6 & 7.65 \\
\hline \multirow[t]{6}{*}{ Skull height } & B & $11.70 \pm 1.39^{c}$ & 89 & 11.84 & $11.29 \pm 1.11^{\mathrm{cd}}$ & 7 & 9.86 \\
\hline & $\mathrm{J}$ & $11.14 \pm 1.78^{c}$ & 72 & 15.97 & $10.45 \pm 1.65^{\mathrm{d}}$ & 22 & 15.82 \\
\hline & $\mathrm{K}$ & $12.58 \pm 1.73^{\mathrm{b}}$ & 193 & 13.78 & $15.00 \pm 1.87^{b}$ & 24 & 12.43 \\
\hline & M & $11.58 \pm 1.20^{c}$ & 48 & 10.36 & $11.33 \pm 1.15^{\mathrm{cd}}$ & 12 & 10.19 \\
\hline & $\mathrm{R}$ & $14.36 \pm 1.47^{\mathrm{a}}$ & 28 & 10.25 & $17.00 \pm 2.83^{\mathrm{a}}$ & 2 & 16.64 \\
\hline & S & $12.94 \pm 1.19^{\mathrm{b}}$ & 36 & 9.22 & $12.50 \pm 1.05^{\mathrm{c}}$ & 6 & 8.39 \\
\hline
\end{tabular}

Note: Means in the same column with different superscript differ significantly ( $\mathrm{P}<0.05)$; $\mathrm{K}=\mathrm{Kacang}$; $\mathrm{B}=\mathrm{Benggala}$; $\mathrm{S}=\mathrm{Samosir}$; J= Jawarandu; $\mathrm{M}=\mathrm{Marica}$; $\mathrm{R}=$ Muara; $\mathrm{n}=$ number of samples; $\mathrm{x}=$ average; $\mathrm{sd}=$ standard deviation; $\mathrm{CV}=$ coefficient variance.

Table 4. Means of tail length and width of Indonesian local goats

\begin{tabular}{|c|c|c|c|c|c|c|c|}
\hline \multirow{2}{*}{ Parameters } & \multirow{2}{*}{$\begin{array}{c}\text { Goat } \\
\text { popula- } \\
\text { tions }\end{array}$} & \multicolumn{3}{|c|}{ Doe } & \multicolumn{3}{|c|}{ Buck } \\
\hline & & $\mathrm{x} \pm \mathrm{sd}(\mathrm{cm})$ & $\mathrm{n}$ & CV $(\%)$ & $\mathrm{x} \pm \mathrm{sd}(\mathrm{cm})$ & $\mathrm{n}$ & $\mathrm{CV}(\%)$ \\
\hline \multirow[t]{6}{*}{ Tail length } & B & $10.22 \pm 2.79^{b}$ & 89 & 27.30 & $7.86 \pm 4.41^{\mathrm{c}}$ & 7 & 56.17 \\
\hline & $\mathrm{J}$ & $11.22 \pm 1.79^{b}$ & 72 & 15.98 & $10.27 \pm 2.31^{\mathrm{bc}}$ & 22 & 22.52 \\
\hline & K & $11.40 \pm 6.47^{\mathrm{b}}$ & 193 & 56.72 & $11.50 \pm 0.98^{\mathrm{b}}$ & 24 & 8.50 \\
\hline & M & $10.13 \pm 1.18^{b}$ & 48 & 11.64 & $9.17 \pm 0.72^{\mathrm{bc}}$ & 12 & 7.83 \\
\hline & $\mathrm{R}$ & $13.96 \pm 1.73^{\mathrm{a}}$ & 28 & 12.40 & $16.50 \pm 3.54^{a}$ & 2 & 21.43 \\
\hline & S & $10.08 \pm 1.99^{\mathrm{b}}$ & 36 & 19.75 & $9.50 \pm 1.05^{\mathrm{bc}}$ & 6 & 11.04 \\
\hline \multirow[t]{6}{*}{ Tail width } & B & $3.92 \pm 1.71^{\mathrm{c}}$ & 89 & 43.53 & $2.71 \pm 0.49^{c}$ & 7 & 17.98 \\
\hline & $\mathrm{J}$ & $1.90 \pm 0.70^{\mathrm{e}}$ & 72 & 36.54 & $1.82 \pm 0.39^{c}$ & 22 & 21.71 \\
\hline & K & $4.73 \pm 0.79^{b}$ & 193 & 16.71 & $4.33 \pm 1.13^{\mathrm{b}}$ & 24 & 26.06 \\
\hline & M & $2.35 \pm 0.48^{\mathrm{d}}$ & 48 & 20.53 & $2.17 \pm 0.72^{c}$ & 12 & 33.13 \\
\hline & $\mathrm{R}$ & $5.29 \pm 1.21^{\mathrm{a}}$ & 28 & 22.94 & $5.50 \pm 0.71^{\mathrm{a}}$ & 2 & 12.86 \\
\hline & S & $4.11 \pm 0.71^{\mathrm{c}}$ & 36 & 17.23 & $3.67 \pm 0.82^{\mathrm{b}}$ & 6 & 22.27 \\
\hline
\end{tabular}

Note: Means in the same column with different superscript differ significantly $(\mathrm{P}<0.05)$; $\mathrm{K}=\mathrm{Kacang}$; $\mathrm{B}=\mathrm{Benggala}$; $\mathrm{S}=\mathrm{Samosir}$; J= Jawarandu; $\mathrm{M}=\mathrm{Marica}$; $\mathrm{R}=$ Muara; $\mathrm{n}=$ number of samples; $\mathrm{x}=$ average; $\mathrm{sd}=$ standard deviation; $\mathrm{CV}=$ coefficient variance. 
compared between each others (Table 4). The highest tail length of doe was Muara significantly different $(\mathrm{P}<0.05)$ compared to others. Kacang was similar to Jawarandu, Benggala, Marica, and Samosir. The highest tail length of buck was Muara significantly different $(\mathrm{P}<0.05)$ compared to the others. Jawarandu similar to Kacang, Samosir and Marica, and the lowest was Benggala. The highest tail width of doe was Muara significantly different $(\mathrm{P}<0.05)$ compared to Kacang, Samosir similar to Benggala, than Marica and the lowest was Jawarandu. The highest tail width of buck was Muara significantly different $(\mathrm{P}<0.05)$ compared to Kacang similar with Samosir, and than Jawarandu similar to Marica and Benggala.

In general, the results showed the average size of ear length and width between populations were significantly different $(\mathrm{P}<0.05)$ between each others (Table 5). The highest ear length of doe was Muara significantly different $(\mathrm{P}<0.05)$ compared to Kacang similar with Jawarandu, than Benggala, and Samosir similar with
Marica. The highest ear length of buck was Muara significantly different $(\mathrm{P}<0.05)$ compared to Jawarandu similar to Marica, Kacang, Samosir, and Marica, and the lowest was Benggala.

The highest ear width of doe were Muara and Samosir significantly different $(\mathrm{P}<0.05)$ compared to Marica, than Benggala similar with Jawarandu, and than the lowest was Kacang. The highest ear width of buck were Muara and Samosir significantly different $(\mathrm{P}<0.05)$ compared to Marica similar to Jawarandu and Kacang, and the lowest was Benggala.

The size of the canon circumference between populations were significantly different $(P<0.05)$ (Table 6). The highest canon circumference of doe was Muara significantly different $(\mathrm{P}<0.05)$ compared to Benggala, than Samosir similar with Jawarandu, than Marica, and the lowest was Kacang. The highest canon circumference of buck was in Muara significantly different $(\mathrm{P}<0.05)$ compared to Samosir similar to Marica, Benggala, and Jawarandu, and the lowest was Kacang goat.

Table 5. Means of ear length and ear width of Indonesian local goats

\begin{tabular}{|c|c|c|c|c|c|c|c|}
\hline \multirow{2}{*}{ Parameters } & \multirow{2}{*}{$\begin{array}{c}\text { Goat } \\
\text { popula- } \\
\text { tions }\end{array}$} & \multicolumn{3}{|c|}{ Doe } & \multicolumn{3}{|c|}{ Buck } \\
\hline & & $\mathrm{x} \pm \mathrm{sd}(\mathrm{cm})$ & $\mathrm{n}$ & $\mathrm{CV}(\%)$ & $\mathrm{x} \pm \mathrm{sd}(\mathrm{cm})$ & $\mathrm{n}$ & $\mathrm{CV}(\%)$ \\
\hline \multirow[t]{6}{*}{ Ear length } & B & $14.63 \pm 2.94^{\mathrm{c}}$ & 89 & 20.12 & $11.86 \pm 1.46^{c}$ & 7 & 12.35 \\
\hline & $\mathrm{J}$ & $15.47 \pm 1.75^{\mathrm{b}}$ & 72 & 11.32 & $14.64 \pm 2.06^{\mathrm{b}}$ & 22 & 14.07 \\
\hline & K & $16.08 \pm 1.96^{\mathrm{b}}$ & 193 & 12.16 & $14.00 \pm 1.02^{\mathrm{b}}$ & 24 & 7.30 \\
\hline & M & $13.38 \pm 1.33^{\mathrm{d}}$ & 48 & 9.95 & $13.50 \pm 1.98^{\mathrm{bc}}$ & 12 & 14.65 \\
\hline & $\mathrm{R}$ & $19.14 \pm 2.86^{\mathrm{a}}$ & 28 & 14.96 & $21.00 \pm 1.41^{\mathrm{a}}$ & 2 & 6.73 \\
\hline & $S$ & $13.92 \pm 1.87^{\mathrm{cd}}$ & 36 & 13.46 & $13.83 \pm 1.17^{\mathrm{b}}$ & 6 & 8.45 \\
\hline \multirow[t]{6}{*}{ Ear width } & B & $15.51 \pm 3.44^{\mathrm{c}}$ & 89 & 22.17 & $10.29 \pm 3.99^{c}$ & 7 & 38.77 \\
\hline & $\mathrm{J}$ & $15.28 \pm 2.08^{c}$ & 72 & 13.60 & $14.27 \pm 1.75^{\mathrm{b}}$ & 22 & 12.27 \\
\hline & K & $12.10 \pm 2.29^{\mathrm{d}}$ & 193 & 18.93 & $13.50 \pm 1.93^{\mathrm{b}}$ & 24 & 14.32 \\
\hline & M & $16.83 \pm 1.99^{\mathrm{b}}$ & 48 & 11.84 & $15.92 \pm 1.73^{\mathrm{b}}$ & 12 & 10.87 \\
\hline & $\mathrm{R}$ & $20.00 \pm 2.51^{\mathrm{a}}$ & 28 & 12.55 & $19.50 \pm 0.71^{\mathrm{a}}$ & 2 & 3.63 \\
\hline & $\mathrm{S}$ & $19.19 \pm 2.21^{\mathrm{a}}$ & 36 & 11.54 & $18.83 \pm 3.13^{\mathrm{a}}$ & 6 & 16.59 \\
\hline
\end{tabular}

Note: Means in the same column with different superscript differ significantly $(\mathrm{P}<0.05) ; \mathrm{K}=\mathrm{Kacang}$; $\mathrm{B}=$ Benggala; $\mathrm{S}=\mathrm{Samosir} ; \mathrm{J}=\mathrm{Jawarandu}$; M= Marica; $\mathrm{R}=$ Muara; $\mathrm{n}=$ number of samples; $\mathrm{x}=$ average; $\mathrm{sd}=$ standard deviation; $\mathrm{CV}=$ coefficient variance.

Table 6. Means of the canon circumference of six different populations of Indonesian local goats

\begin{tabular}{|c|c|c|c|c|c|c|c|}
\hline \multirow{2}{*}{ Parameters } & \multirow{2}{*}{$\begin{array}{l}\text { Goat } \\
\text { popula- } \\
\text { tions }\end{array}$} & \multicolumn{3}{|c|}{ Doe } & \multicolumn{3}{|c|}{ Buck } \\
\hline & & $\mathrm{x} \pm \mathrm{sd}(\mathrm{cm})$ & $\mathrm{n}$ & $\mathrm{CV}(\%)$ & $\mathrm{x} \pm \mathrm{sd}(\mathrm{cm})$ & $\mathrm{n}$ & CV (\%) \\
\hline \multirow{6}{*}{$\begin{array}{l}\text { Canon circum } \\
\text { ference }\end{array}$} & B & $14.64 \pm 1.65^{\mathrm{b}}$ & 89 & 11.24 & $13.43 \pm 0.53^{\mathrm{b}}$ & 7 & 3.98 \\
\hline & $\mathrm{J}$ & $13.83 \pm 1.67^{\mathrm{c}}$ & 72 & 12.07 & $13.27 \pm 1.58^{b}$ & 22 & 11.90 \\
\hline & K & $7.73 \pm 0.69^{\mathrm{e}}$ & 193 & 8.98 & $9.17 \pm 0.38^{\mathrm{c}}$ & 24 & 4.15 \\
\hline & M & $13.29 \pm 1.07^{\mathrm{d}}$ & 48 & 8.06 & $13.83 \pm 0.94^{\mathrm{b}}$ & 12 & 6.78 \\
\hline & $\mathrm{R}$ & $16.71 \pm 1.46^{\mathrm{a}}$ & 28 & 8.75 & $19.50 \pm 4.95^{\mathrm{a}}$ & 2 & 25.38 \\
\hline & S & $14.11 \pm 1.26^{\mathrm{c}}$ & 36 & 8.93 & $14.67 \pm 0.82^{\mathrm{b}}$ & 6 & 5.57 \\
\hline
\end{tabular}

Note: Means in the same column with different superscript differ significantly ( $\mathrm{P}<0.05)$; K= Kacang; $\mathrm{B}=\mathrm{Benggala}$; $\mathrm{S}=\mathrm{Samosir}$; J= Jawarandu; M= Marica; $\mathrm{R}=$ Muara; $\mathrm{n}=$ number of samples; $\mathrm{x}=$ average; $\mathrm{sd}=$ standard deviation; $\mathrm{CV}=$ coefficient variance. 


\section{Maps of the Goat Phenotypic Measurements Distributions}

The six populations of goat research showed a high diversity of morphologically in Muara, Jawarandu, Kacang, Marica, Samosir, and Benggala goats (Figure 1 ). The diversity of morphology can occur because of the mutation process of selection (natural and artificial), crossbreeding, genetic drift that can result in lost or run off of certain genes (Anderson, 2001). Figure 1 showed that the grouping of the six population Indonesian goat research into 6 groups, namely: (1) the Muara goat (R) was in quadrant I, (2) groups of Jawarandu goats (J) was largely in quadrant I and quadrant IV, (3) group of Kacang goats in quadrant II, (4) the majority of Benggala goat was in quadrant III and a small portion was in quadrant IV, (5) Marica goat groups in quadrant III and quadrant IV, and (6) group Samosir goat similar to the Marica in quadrant III and quadrant IV. Muara goat was a group that far apart when compared with other genotypes, it alleged Muara goat was a spesific breed goat of its own.

Kacang goat breeds rather far from the groups of Jawarandu, Samosir, Marica, and Benggala, that may be caused of the samples of Kacang goats were from Indonesian Goat Research Institute station, which has been selected and better maintenance management, so that relatively larger body size compare to Kacang in Farmers. The characteristics of body size Marica goat's in South Sulawesi Province, Samosir goat in North Tapanuli regency, North Sumatra Province were relatively closer. This was apparently due to adaptation to the environment that almost simultaneously with the conditions foods availibity. Environment as a limiting factor for livestock in the area, effect of feed availability, which in South Sulawesi province has the dry season between 6-9 months in 1 year and soil conditions were relatively had thin of top soil. While in Samosir regency despite relatively high rainfall, the top soil conditions similar to conditions in South Sulawesi was relatively thin of the top soil and rocky.

\section{The Value of Inter-Group Phenotypic Mixture}

The result of discriminate analysis can be used to predict the existence of common values in a group of goats. Most likely the proportion of values that affect the similarity of a mixture of other populations based on phenotypic similarity measure (Riva et al., 2004; Sumantri et al., 2007; Carnerio et al. 2010; Jing et al. 2010). The results analysis of similarity and mixed in among the group showed that Samosir goats was the lowest similarity with value $82.50 \%$ because developed by mixture of Muara $7.50 \%$, Benggala 5\%, and Marica goat

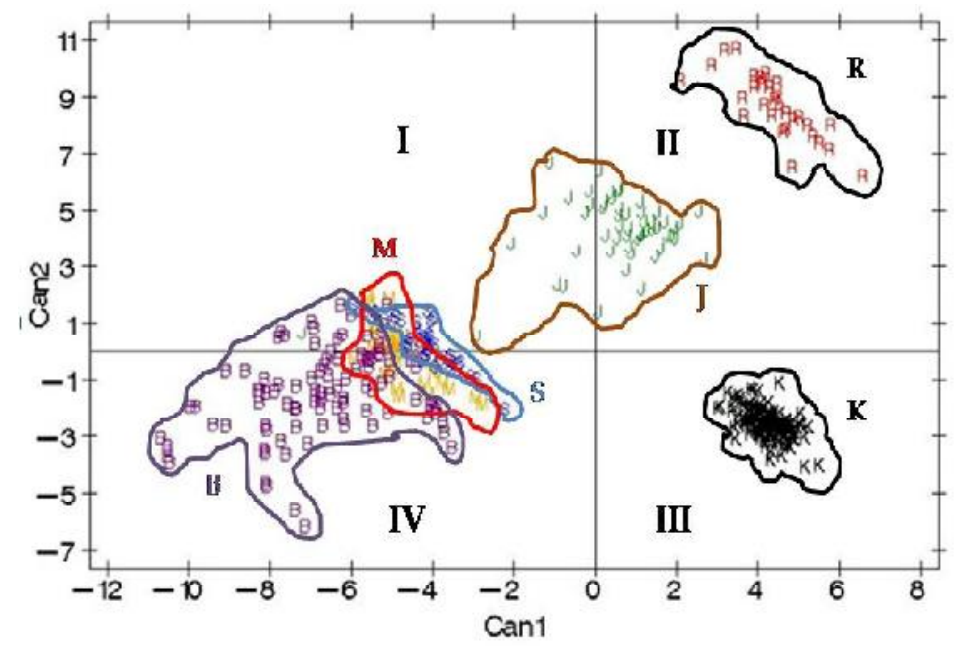

Figure 1. The distribution of canonical goat groups according to the phenotypic measurement of the 6 populations of Indonesian local goats. $\mathrm{K}=$ Kacang; $\mathrm{B}=$ Benggala; $\mathrm{S}=$ Samosir; J= Jawarandu; $\mathrm{M}=$ Marica; $\mathrm{R}=$ Muara.

Table 7. The percentages of similarity and mixed within and between groups of six goat different population of Indonesian local goats $(\%)$

\begin{tabular}{lccccccc}
\hline $\begin{array}{l}\text { Goat sub } \\
\text { populations }\end{array}$ & Benggala & Jawarandu & Kacang & Marica & Muara & Samosir & Total \\
\hline Benggala & 88.57 & 0.00 & 0.00 & 5.71 & 0.00 & 5.71 & 100.00 \\
Jawarandu & 2.17 & 91.30 & 0.00 & 6.52 & 0.00 & 0.00 & 100.00 \\
Kacang & 0.00 & 0.00 & 99.28 & 0.73 & 0.00 & 0.00 & 100.00 \\
Marica & 0.00 & 10.00 & 0.00 & 83.33 & 0.00 & 6.67 & 100.00 \\
Muara & 0.00 & 0.00 & 0.00 & 0.00 & 93.33 & 6.67 & 100.00 \\
Samosir & 5.00 & 2.50 & 0.00 & 2.50 & 7.50 & 82.50 & 100.00 \\
\hline
\end{tabular}


$2.5 \%$ (Table 7). Marica goat group had $83.33 \%$ similarity value, because of the effect of Jawarandu $10 \%$ and Samosir goats $6.67 \%$. Benggala goats group has similarity value $88.57 \%$, because expand by mixture of Marica and Samosir goat with the value of each genotype goats at $5.71 \%$. Jawarandu goat group had $91.30 \%$ similarity value because expand by mixture of Marica $6.52 \%$ and Banggala goat $2.17 \%$. Muara goat group has the highest similarity value of $93.33 \%$, because only influenced by the value of a mixture of Samosir goat $6.67 \%$. Genetic and environmental factors have a close relationship, and to express their genetic capacity of individuals are perfectly necessary environmental conditions were ideal (Noor, 2002; Fajemilehin \& Salako, 2008).

\section{Determigenotype of the Genetic Distance and the Phenogram Tree}

The value matrix of genetic distances between group 6 populations of goats (Table 8 ) were used to make construction phenogram tree (Figure 2). Phenogram tree depicts the overall genetic distance group. The analysis result in Table 8 shows that the smallest value obtained at a distance of two groups of Samosir and Marica goat is equal to 11.207. The largest value obtained from the Muara-Benggala goats (255.110), followed by MuaraMarica (187.865), as well as Kacang-Benggala goats (139.942) and Muara-Kacang goats (133.471). The matrix value of genetic distance obtained from a relatively large genetic distance between Muara goat-all groups, and genetic distance Kacang-Benggala goats.

The construction of phenogram tree (Figure 2) shows that the group Samosir-Marica goats and MaricaBenggala has a genetic distance close compared genetic distance Samosir-Benggala (22.888) and JawaranduMarica goat (51.890). Muara goat groups in North Tapanuli Regency, North Sumatra Province was genetically separated from the Benggala, Kacang, Marica, and Samosir goats. Muara goat genetic distance showed from the branches of the tree in Figure 2 which showed that the branch indirect link between Marica, Samosir, Benggala, and Kacang goats.

Distribution map based on body size and phenogram tree some goats in one breeds should be cross breed mating program to increase genetic variation. Bourdon (2000) suggested that a crossing between individuals that have a genetic distance away would give better performance than the average of the parent, due to increased heterozygosis and gene comb genotypes. Based on this genetic distance and the phenogram tree the six population of Indonesian local goat could be classified into six breeds of goats which separated one sub breed to the others breeds.

\section{Discriminant Variables Goat Breeds}

The result shows that the parameter has strong influence on the breed groups were the circumference of canon (0.671 Can-1) and (0.666 Can-2), body length (0.669 Can-3), skull width (0.523 Can-3), skull height (0.529 Can-3), and tail width (0.714 Can-4), so that the circumference of the canon, body length, skull width, skull height, and tail width could be used as discriminator variables local goat groups in Indonesia (Table 9).

Table 8. Matrix genetic distance between groups of six populations of Indonesian local goats

\begin{tabular}{|c|c|c|c|c|c|c|}
\hline $\begin{array}{l}\text { Goat } \\
\text { populations }\end{array}$ & Benggala & Jawarandu & Kacang & Marica & Muara & Samosir \\
\hline Benggala & 0 & & & & & \\
\hline Jawarandu & 97.977 & 0 & & & & \\
\hline Kacang & 139.942 & 66.599 & 0 & & & \\
\hline Marica & 15.339 & 51.890 & 98.214 & 0 & & \\
\hline Muara & 255.110 & 64.170 & 133.471 & 187.865 & 0 & \\
\hline Samosir & 22.888 & 57.964 & 93.086 & 11.207 & 162.586 & 0 \\
\hline
\end{tabular}
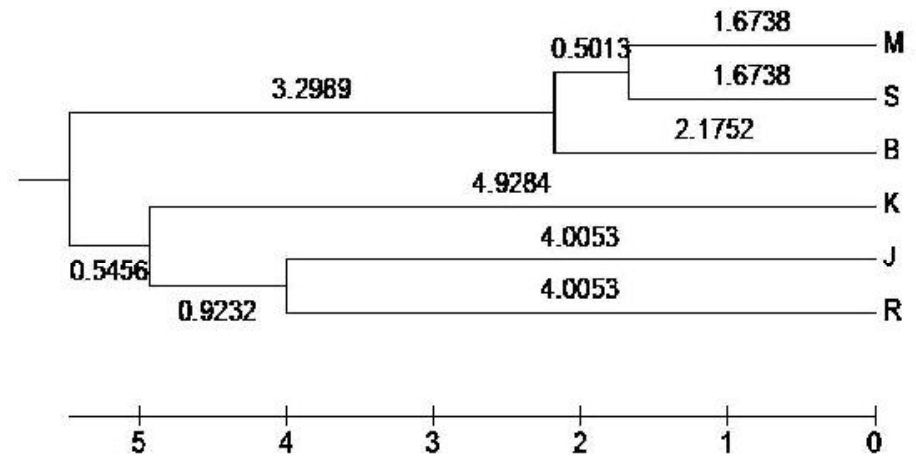

Figure 2. The phenogram tree according to the phenotypic measurements of the six populations of Indonesian local goats. $\mathrm{K}=\mathrm{Ka}-$ cang; $\mathrm{B}=$ Benggala; $\mathrm{S}=$ Samosir; J= Jawarandu; $\mathrm{M}=$ Marica; $\mathrm{R}=$ Muara. 
Table 9. Matrix genetic distance between groups of six populations of Indonesian local goats

\begin{tabular}{|c|c|c|c|c|}
\hline Variable & Can-1 & Can-2 & Can-3 & Can-4 \\
\hline Body weight & 0.04 & 0.26 & 0.48 & -0.21 \\
\hline Body length & 0.02 & 0.03 & 0.67 & -0.17 \\
\hline Chest circumference & -0.03 & 0.21 & 0.46 & -0.28 \\
\hline Chest width & -0.18 & 0.03 & 0.07 & 0.52 \\
\hline Wither height & 0.22 & 0.11 & 0.50 & -0.29 \\
\hline Chest depth & 0.33 & 0.30 & 0.05 & 0.46 \\
\hline Rump circummence & 0.00 & 0.18 & 0.37 & -0.23 \\
\hline Rump width & -0.45 & 0.46 & 0.44 & 0.24 \\
\hline Rump height & 0.30 & 0.25 & 0.34 & -0.05 \\
\hline Rump depth & 0.33 & 0.00 & 0.07 & 0.09 \\
\hline Canon circumference & 0.67 & 0.67 & 0.20 & -0.11 \\
\hline Horn length & -0.09 & 0.24 & 0.24 & -0.09 \\
\hline Ear length & 0.40 & 0.18 & 0.26 & -0.37 \\
\hline Ear width & -0.31 & 0.46 & 0.37 & 0.36 \\
\hline Skull length & 0.24 & -0.32 & 0.18 & -0.39 \\
\hline Skull width & 0.28 & 0.11 & 0.52 & -0.14 \\
\hline Skull height & 0.29 & -0.06 & 0.53 & 0.01 \\
\hline Tail length & 0.17 & 0.04 & 0.09 & -0.07 \\
\hline Tail width & 0.37 & -0.35 & 0.71 & -0.31 \\
\hline
\end{tabular}

\section{CONCLUSION}

Muara goat has the livebody weight and body linier measurement was larger when compared with Jawarandu, Benggala, Kacang, Samosir, and Marica goat. The canon circumference, body weight, body length, skull width, skull height and tail width were the most discriminant variable to determine the differences between breeds of Indonesian local goats. The diversity of body size and body weight of goats were observed quite large, so the chances of increased productivity could be made through selection and mating programs.

\section{ACKNOWLEDGEMENT}

Financial support was provided by the Agency for Agricultural Research and Development which has funded this research. The authors wish acknowdgements to all cooperation and the assistance during field sampling to the Head of BPTP South Sulawesi, the Head of BPTP Nusa Southeast Timor province, The Head of Animal Husbandry Service of Blora Regency - Central Java province, The Head of Fisheries and Livestock Services Regency of North Tapanuli, The Head of Agriculture, Livestock and Fisheries Services of Samosir Regency. In particular conveyed his gratitude for the good cooperation during the field to Mr. Ir. Erwin Sihite, Ir. Mateus Sariubang, MSi, Ir. Daniel Pasambe, Ir. Bonggas Pasaribu, drh. Wasito M.Si., Mrs. Ir. Deborah Kana Hau, M.Si., and Ir. Rosianna Tarigan. Also many thanks to all the officers and many farmers who provided assistance during data collection in the fields.

\section{REFERENCES}

(FAO) Food and Agriculture Organization. 2007. The Global Plan of Action for Animal Genetic resources and Interlaken Declarations on Animal Genetic Resources. Intergenotypeal Technical Conference on Animal Genetic Resources for Food and Agriculture, Interlaken, 3-7 September 2007. Switzerland. Food and Agriculture Organization (FAO). Rome, Italy.

Alade, N. K., A. O. Raji, \& M. A. Atiku. 2008. Determination of apropriate model for the estimation of body weight in goats. J. Agric. Biol. Sci. 3:51-57.

Anderson, L. 2001. Genetic dissection of phenotypic diversity in farm animals. Nature Rev. Genet. 2:130-138.

Bourdon, R. M. 2000. Understanding Animal Breeding. 2nd Ed. Prentice-Hall, New Jersey, USA.

Carnerio, H., H. Louvandini, S. R. Paiva, F. Macedo, B. Mernies, \& C. McManus. 2010. Morphological characterization of sheep breeds in Brazil, Uruguay and Colombia. J. Small Rum. Res. 94:58-65.

Directorate General of Livestock Service. 2010. Livestock Statistic 2009. Directorate General of Livestock Service. The Ministry of Agricultural of Republic of Indonesia, Jakarta.

Dossa, L. H., C. Wollmy, \& M. Gauly. 2007. Spatial variation in goat populations from Benin as revealed by multivariate analysis of morphological traits. J. Small Rum. Res. 73:150159.

Everitt, B. \& G. Dunn. 2001. Applied Multivariate Data Analysis. 2nd Ed. Oxford University Press. pp.342.

Fajemilehin, O. K. \& A. E. Salako. 2008. Body measurement characteristics of the West African Dwarf (WAD) goat in deciduous forest zone of Southwestern Nigeria. African J. of Biotec. 7:2521-2526.

Flury, B. 1988. Common Principal Components and Related Multivariate Models. John Wiley, New York. 
Herrera, M., E. Rodero, M. J. Gutierrez, F. Pena, \& J. M. Rodero. 1996. Application of multifactorial discriminant analysis in the morphostructural differentiation of Andalusian caprine breeds. J. Small Rum. Res. 22:39-47.

Jimmy, S., M. David, K. R. Donald, \& M. Dennis. 2010. Varibiality in body measurement and their application in predicting libe bofy weight of Mubende and Small East African goat breeds in Uganda. Middle-East J. of Scient. Res. 5:98-105.

Jing, L, J. Ren-jun, Z. Guo-rong, Y. Qing-ran, \& M. Hua-ming. 2010. Quentitative and qualitative body traits of longling yellow goats in China. J. Agric. Sci. in China 9:408-415.

Karna, D. K., G. L. Koul, \& G. S. Bisht. 2001. Pashmina yield and its association with mophometric traits in Indian Cheghu goats. J. Small Rum. Res. 41:271-275.

Khan, H., F. Muhammad, R. Ahmad, G. Nawaz, Rahimullah, \& M. Zubair. 2006. Relationship of body weight with linear body measurements in goats. J. Agric. Biol. Sci. 1:51-54.

Kumar, S., K. Tamura, \& M. Nei. 1993. MEGA: Molecular Evolutionary Genetics Analysis. Pennsylvania State University, University Park, PA.

Lanari, M. R., H. Taddeo, E. Domingo, M. M. Centeno, \& L. Gallo. 2003. Phenotypic differentiation of exterior traits in local criollo goat population in Patagonia (Argentina). Archive Tierzh. Dummerstorf 46:347-356.

Mansjoer, S. S., T. Kertanugraha, \& C. Sumantri. 2007. Estimasi jarak genetik antar domba garut tipe tangkas dengan tipe pedaging. Med. Pet. 30:129-138.

Nei, S. \& M. Nei. 1987. The neighbor-joining method: a new method for reconstructing phylogenetic trees. J. Mol. Biol. Evol. 4:406-425

Noor R. R. 2002. Genetika Ekologi. Laboratorium Pemuliaan dan Genetika Ternak. Fakultas Peternakan, Institut Pertanian Bogor, Bogor.

Quinn, G. P. \& M. J. Keough. 2002. Experimental Design and Data Analysis for Biologist. Cambridge University Press, Cambridge, U.K., pp.537.
Riva, J., R. Rizzi, S. Marelli, \& L.G. Gavalchini. 2004. Body measurements in Bergamasca sheep. J. Small Rum. Res. 55:221-227.

Salako, A. E. 2006. Principal component factor analysis of the morphostructure of immature Uda sheep. Internat. J. Morphology 24:571-574.

SAS Institute. 2005. SAS / STAT Guide for Personal Computer. Version 9.1. SAS Institute Cary, NC. USA.

Setiadi, B., I. K. Sutama, \& I. G. M. Budiarsana. 1997. Efisiensi reproduksi dan produksi kambing Peranakan Etawah pada berbagai tatalaksana perkawinan. J. Ilmu Ternak Vet. 2:233-236.

Setiadi, B., Subandriyo, \& L. C. Iniguez. 1995. Reproductive performance of small ruminants in an Outreach Pilot Project in West Java. J. Ilmu Ternak Vet. 1:73-80.

Sitepu, P. 1985. Produktivitas ternak kambing di Propinsi Sumatera Utara: Ukuran tubuh dan morfogenetik kambing lokal di Kecamatan Galang. J. Ilmu Pet. 2:5-9.

Subandriyo, B. Setiadi, D. Priyanto, M. Rangkuti, W. K. Sejati, D. Anggraeni, R. S. G. Sianturi, Hastono, \& O. Butarbutar. 1995. Analisis Potensi Kambing Peranakan Etawah dan Sumberdaya di Daerah Sumber Bibit Pedesaan. Pusat Penelitian dan Pengembangan Peternakan.

Sumantri, C. A., A. Einstiana, J. F. Salamena, \& I. Inounu. 2007. Keragaman dan hubungan phylogenik antar domba lokal di Indonesia melalui pendekatan analisis morfologi. J. Ilmu Ternak Vet. 12 : 42-54.

Tamura K., J. Dudley, M. Nei, \& S. Kumar. 2007. MEGA 4: Molecular Evolutionary Genetic Analysis (MEGA) software version 4.0. J. Biol. Evol. 24: 1596-1599.

Traore A., H. M. Tamboura, A. Kabore, L. J. Royo, I. Fernandez, I. Alvarez, M. Sangare, D. Bouchel, J. L. Poivey, D. Franscois, L. Sawadogo, \& F. Goyache. 2008. Multivariate's analysis on morphological traits of Goats in Burkina Faso. Arch. Tierz., Dummerstorf 6: 588-600. 